\title{
PENERAPAN PENDEKATAN SAINTIFIK DENGAN METODE DISKUSI KELOMPOK UNTUK MENINGKATKAN MOTIVASI DAN HASIL BELAJAR IPS MATERI MENGHARGAI PERJUANGAN PARA TOKOH DALAM MEMPERTAHANKAN KEMERDEKAAN
}

\author{
Sri Endah Wahyuni \\ SDN 1 Karanganyar Patikraja, Banyumas, Indonesia \\ Email: sriendahwahyuni@gmail.com
}

\begin{abstract}
The purpose of this research is to increase student motivation and learning outcomes/result of $5^{\text {th }}$ grade SDN 1 Karanganyar Patikraja Banyumas for Social lesson with the topic to Appreciating the Characters Struggle to maintain independence through the application of scientific approach. This Research is using Classroom Actions Research which implemented in two cycles, each cycle consisting of four stage, those stages are planning/designs, actions, observations, and reflections. Data collection can be done by test, observation and questionnaire. Indicator of the success of actions in this research is if the increasing of student motivation is at least $80 \%$ from the maximal score from all students and if the increasing of learning outcomes is at least $85 \%$ from all students has reach KKM of Social lesson 68. This research conclude that: First, Application of the Scientific Approach with group discussion method can increase student motivation in social lesson for the topic to Appreciating the Characters Struggle to maintain independence of $5^{\text {th }}$ grade SDN 1 Karanganyar Patikraja Banyumas.
\end{abstract}

Keywords : Learning Motivations, Learning Outcomes, Scientific Approach, Group Discuss Method.

Abstrak. Tujuan dari penelitian ini adalah untuk meningkatkan motivasi dan hasil belajar / hasil belajar siswa kelas V SDN 1 Karanganyar Patikraja Banyumas untuk pelajaran sosial dengan topik Apresiasi Perjuangan Karakter untuk mempertahankan kemandirian melalui penerapan pendekatan ilmiah. Penelitian ini menggunakan Penelitian Tindakan Kelas yang dilaksanakan dalam dua siklus, setiap siklus terdiri dari empat tahap, tahapan-tahapan tersebut adalah perencanaan/desain, tindakan, pengamatan, dan refleksi. Pengumpulan data dapat dilakukan dengan tes, observasi dan kuesioner. Indikator keberhasilan tindakan dalam penelitian ini adalah jika peningkatan motivasi siswa setidaknya $80 \%$ dari skor maksimal dari semua siswa dan jika peningkatan hasil belajar setidaknya 85\% dari semua siswa telah mencapai KKM pelajaran sosial 68 Penelitian ini menyimpulkan bahwa: Pertama, Penerapan Pendekatan Ilmiah dengan metode diskusi kelompok dapat meningkatkan motivasi siswa dalam pelajaran sosial untuk topik Menghargai Perjuangan Karakter untuk menjaga kemandirian siswa kelas V SDN 1 Karanganyar Patikraja Banyumas Kedua, Penerapan Pendekatan Ilmiah dengan metode diskusi kelompok dapat meningkatkan hasil / hasil belajar pada pelajaran sosial untuk topik Menghargai Perjuangan Karakter untuk mempertahankan kemandirian siswa kelas V SDN 1 Karanganyar Patikraja Banyumas.

Kata kunci: Motivasi Belajar, Hasil Belajar, Pendekatan Ilmiah, Metode Diskusi Kelompok.

\section{PENDAHULUAN}

Ilmu Pengetahuan Sosial (IPS) merupakan salah satu matapelajaran yang mengkaji seperangkat peristiwa, fakta, konsep, dan generalisasi yang berkaitan dengan isu sosial. Mata pelajaran ini membekali peserta didik agar memiliki pengetahuan sosial, keterampilan sosial, serta kepedulian sosial sebagai sumber daya manusia yang bertanggung jawab dalam merealisasikan tujuan pendidikan nasional. Mata pelajaran ini diarahkan agar peserta didik menjadi warga negara Indonesia yang demokratis, cerdas, terampil, dan bertanggung jawab, serta menjadi warga 
dunia yang cinta damai (Ahmadi dan Amri, 2011:9-10).

Keberhasilan proses pembelajaran IPS dipengaruhi oleh banyak faktor, salah satunya adalah penggunaan atau pemilihan pendekatan pembelajaran yang tepat dengan materi pembelajaran. Penggunaan pendekatan yang tidak tepat dapat menimbulkan permasalahan di dalam proses pembelajaran di kelas dan dapat menghambat keberhasilan proses pembelajaran.

Berdasarkan pengalaman dan pengamatan peneliti selama ini, selaku guru Kelas V SDN 1 Karanganyar Patikraja Banyumas, bahwamasalah yang masihseringterjadi di kelas ketika pembelajaran IPS adalah rendahnya motivasi siswa dalam mengikuti pembelajaran. Permasalahan tersebut dapat terlihat dari kondisi siswa yang sebagian besar kurang terlibat dalam pembelajaran, yaitu kurang aktif, kurang dinamis, dan kurang kreatif. Secara umum, mereka hanya melihat, mendengar, menulis dan mengerjakan. Mereka padasaat mereka diberi pertanyaan, sebagian besar hanya diam dan menundukkan kepala.Kalau pun ditunjuk oleh guru, mereka seakan malas untuk menjawab pertanyaan. Kondisi ini berdampakpadatidakhidupnya proses pembelajaran, yaitu siswa hanya terbiasa menerima, kurang berpartisipasi secaraktif, jarang menyampaikan pertanyaan, pendapat, usul, dan sanggahan dalam pembelajaran.

Rendahnya motivasi siswa dalam proses pembelajaran IPS berdampak pada rendahnya hasil belajar mereka. Hal itu terlihat dari perolehan nilai ujian akhir mereka di semester satu tahun pelajaran 20113-2014, masih banyak siswa yang belum mencapai Kriteria Ketuntasan Minimum (KKM) yang telah ditetapkan sekolah yaitu 68. Dari 26 siswahanya 19 siswa yang memenuhi KKM dan selebihnya yaitu 7 siswa mendapat nilai masih di bawah KKM.

Berdasarkan permasalahan tersebut, maka perlu dilakukan tindakan yang dapat meningkatkan motivasi dan prestasi belajar siswa dalam mata pelajaran IPS. Upaya yang dapat ditempuh salah satunya adalah melalui penerapan pendekatan saintifik dengan metode diskusi kelompok dalam pembelajaran. Tindakan ini dipilih didasarkan pertimbangan bahwa pendekatan saintifik dengan metode diskusi kelompok memuat langkah-langkah pembelajaran yang memungkinkan siswa dapat mengoptimalkan motivasikarena menuntut mereka berpartisipasi aktif sejak dari awal sampai akhir pembelajaran, terutama dengan sesama anggota kelompoknya. Dengan demikian, diharapkan pula hasil belajar mereka dapat meningkat. Pertimbangan lainnya, didasarkan pada adanya kebijakan dalam pelaksanaan kurikulum 2013 yang menetapkan pendekatan saintifik sebagai pendekatan yang dituntut digunakan oleh guru dalam proses pembelajaran.

\section{METODE PENELITIAN}

Penelitian ini dilaksanakan selama tiga bulan, yaitu dari bulan Mei sampai dengan bulan Juli tahun pelajaran 20132014 di SDN 1 Karanganyar Patikraja Banyumas. Subyek penelitian adalah siswa kelas V SDN 1 Karanganyar Patikraja dengan jumlah 26 siswa, terdiri dari 10 lakilaki dan 16 perempuan. Kelas ini dipilih karena tingkat motivasi belajar siswa dalam mengikuti pembelajaran IPS masih kurangdan hasil belajar mereka belum memenuhi KKM yang ditetapkan oleh sekolah yaitu 68. Teknik pengumpulan data di dalam penelitian ini menggunakan teknik observasi, angket, dan tes.

Teknik observasi digunakan untuk mengumpulkan data tentang aktivitas guru, aktivitas siswa, penilaian hasil belajar afektif, dan penilaian hasil belajar psikomotor. Angket digunakan untuk mengumpulkan data tentang motivasi belajar siswa. Tes digunakan untuk mengumpulkan data tentang hasil belajar kognitif. Adapun alatnya berupa lembar observasi aktivitas guru, lembar observasi aktifitas siswa, lembar penilaian afektif, 
lembar penilaian psikomotor, angket motivasi belajar, dan tes hasil belajar kognitif. Data-data tersebut dianalisis dengan deskriptif kuantitaif persentase dan deskriptif kualitatif. Untuk mendapatkan gambaran tentang keberhasilan ketercapaian indikator tindakan digunakan analisis komparatif perolehan motivasi belajar dan hasil belajar siswa antar siklus.

Prosedur penelitian menggunakan langkah-langkah Penelitian Tindakan Kelas, yaitu penelitian yang mengangkat masalahmasalah aktual yang dilakukan guru hasil pencermatan kegiatan pembelajarandengan melakukan tindakan untuk memperbaiki dan meningkatkan praktik pembelajaran di kelas secara lebih profesional. Penelitian tindakan ini dilaksanakan dalam 2 siklus, karena pada dua siklus itu hasilnya sudah mencapai indikator keberhasilan yang ditetapkan, yaitu apabila peningkatan motivasi belajar siswa kelas V SDN 1 Karanganyar dalam mengikuti pembelajaran IPS materi Menghargai Perjuangan Para Tokoh dalam Mempertahankan Kemerdekaan sekurangkurangnya memperoleh nilai 80 tergolong dalam kategori sangat baik, dan apabila peningkatan hasil belajar yang diperoleh siswa sekurang-kurangnya $85 \%$ jumlah siswa telah mencapai KKM yaitu 68. Prosedur penelitian pada setiap siklusnya meliputi tahapan perencanaan, pelaksaaan tindakan, observasi, dan refleksi.

\section{HASIL DAN PEMBAHASAN Peningkatan Motivasi Belajar}

Peningkatan motivasi belajar siswa pada penelitian tindakan kelas ini dapat dilihat pada Tabel 1. berikut:

\section{Tabel 1.}

\section{Peningkatan Hasil Angket Motivasi Belajar Siswa}

\begin{tabular}{|l|l|l|}
\hline \multirow{2}{*}{ Keterangan } & \multicolumn{2}{c|}{ SKOR } \\
\cline { 2 - 3 } & \multicolumn{1}{c|}{ Siklus I } & \multicolumn{1}{c|}{ Sklus II } \\
\hline Jumlah Siswa & 25 & 25 \\
\hline Jumlah skor perolehan & 1.061 & 1.066 \\
\hline Jumlah skor maksimal $(4 \times 13 \times 25)$ & 1.300 & 1.300 \\
\hline Nilai & 82 & 82 \\
\hline Kriteria & Sangat baik & Sangat baik \\
\hline
\end{tabular}

Berdasarkan Tabel 1 terlihat bahwa terjadi peningkatan motivasi belajar siswa pada siklus I ke siklus II, walaupun peningkatan tersebut tidak terlalu besar.

\section{Peningkatan Hasil Belajar Ranah Kognitif}

Peningkatan hasil belajar siswa ranah kognitif dapat dilihat pada tabel 2.

Tabel 2.

Peningkatan Pencapaian Nilai Ranah Kognitif

\begin{tabular}{|l|l|l|l|}
\hline NO & \multicolumn{1}{|c|}{ PENCAPAIAN } & \multicolumn{1}{|c|}{ SIKLUS I } & \multicolumn{1}{|c|}{ SIKLUS II } \\
\hline 1 & Jumlah siswa & 25 & 25 \\
\hline 2 & Jumlah total nilai seluruh siswa & 1842 & 2042 \\
\hline 3 & Rata-rata nilai & 74 & 82 \\
\hline 4 & Nilai tertinggi & 88 & 96 \\
\hline 5 & Nilai terendah & 52 & 68 \\
\hline 6 & KKM belajar & 68 & 68 \\
\hline 7 & $\begin{array}{l}\text { Jumlah } \\
\text { (Mencapai KKM) }\end{array}$ & $22(88 \%)$ & $25(100 \%)$ \\
\hline 8 & Kriteria ketuntasan $\%$ Sangat Baik & Sangat Baik \\
\hline 9 & Jumlah siswa belum tuntas belajar & $3(12 \%)$ & $\begin{array}{l}85 \% \\
\text { siswa } \\
\text { mencapai } \\
\text { KKM }\end{array}$ \\
\hline 10 & Indikator keberhasilan tindakan & $\begin{array}{l}85 \% \\
\text { siswa mencapai } \\
\text { KKM }\end{array}$ & \\
\hline
\end{tabular}



Berdasarkan Tabel 2 di atas terlihat terjadi peningkatan hasil belajar siswa ranah kognitif melalui lembar soal pada siklus I. Pada siklus ini diperoleh rata-rata nilai di atas KKM sebesar 74. Jumlah siswa yang tuntas adalah 22 siswa dari 25 jumlah seluruh siswa, sedangkan siswa yang tidak tuntas adalah 3 siswa. Persentase ketuntasan yang dicapai pada siklus I mencapai $88 \%$, sehingga hasil belajar siswa ranah kognitif dapat dikatakan tuntas dan mencapai indikator. Namun demikian, masih ada tiga orang siswa yang belum mencapai KKM.
Pada siklus II, diperoleh pencapaian bahwa rata-rata nilai isiswa sebesar 82 di atas nilai KKM yang sudah ditentukan. Jumlah siswa yang tuntas pada hasil belajar adalah 25 siswa dari 25 jumlah seluruh siswa, dan tidak ada siswa yang tidak tuntas. Dengan demikian, persentase ketuntasan yang dicapai pada siklus IIsudah mencapai $100 \%$, sehingga hasil belajar siswa ranah kognitif dapat dikatakan melampaui indikator keberhasilan tindakan yang ditetapkan sebesar $85 \%$ dari jumlah siswa.

Peningkatan Hasil Belajar Ranah Afektif Peningkatan hasil belajar siswa ranah psikomotor dapat dilihat pada Tabel 3.

Tabel 3.

Peningkatan Hasil Belajar Siswa Ranah Afektif

\begin{tabular}{|c|c|c|c|c|c|}
\hline \multirow[b]{2}{*}{$\begin{array}{l}\mathbf{N} \\
\mathbf{O}\end{array}$} & \multirow[b]{2}{*}{ INDIKATOR } & \multirow{2}{*}{$\begin{array}{c}\text { ITE } \\
\mathbf{M}\end{array}$} & \multirow[b]{2}{*}{ SIKAP } & \multicolumn{2}{|c|}{ SKOR } \\
\hline & & & & SIKLUS I & $\begin{array}{l}\text { SIKLUS } \\
\text { II }\end{array}$ \\
\hline \multirow[t]{2}{*}{1} & \multirow[t]{2}{*}{$\begin{array}{l}\text { Kemauan } \\
\text { menerima }\end{array}$} & A & $\begin{array}{l}\text { Mau memperhatikan } \\
\text { penjelasan guru }\end{array}$ & 76 & \\
\hline & & & $\begin{array}{l}\text { Mau menerima masukan } \\
\text { pendapat teman }\end{array}$ & 77 & \\
\hline \multirow[t]{2}{*}{2} & \multirow[t]{2}{*}{$\begin{array}{l}\text { Kemauan } \\
\text { menanggapi }\end{array}$} & B & $\begin{array}{l}\text { Mengajukan pertanyaan } \\
\text { atau tanggapan dalam } \\
\text { berdiskusi }\end{array}$ & 75 & \\
\hline & & & $\begin{array}{l}\text { Melengkapi pendapat } \\
\text { teman dalam berdiskusi }\end{array}$ & 80 & \\
\hline \multirow[t]{2}{*}{3} & \multirow[t]{2}{*}{ Berkeyakinan } & $\mathrm{C}$ & $\begin{array}{l}\text { Menunjukkan } \\
\text { kepercayaan diri ketika } \\
\text { mengemukakan } \\
\text { pendapat }\end{array}$ & 82 & \\
\hline & & D & $\begin{array}{l}\text { Bertanggung jawab } \\
\text { terhadap tugas yang } \\
\text { diberikan }\end{array}$ & 86 & \\
\hline 4 & $\begin{array}{l}\text { Ketekunan dan } \\
\text { ketelitian }\end{array}$ & $\mathrm{E}$ & $\begin{array}{l}\text { Menyelesaikan tugas } \\
\text { yang diberikan }\end{array}$ & 88 & \\
\hline 5 & $\begin{array}{l}\text { Mengorganisasika } \\
\mathrm{n}\end{array}$ & F & $\begin{array}{l}\text { Menjalin kekompakan } \\
\text { dalam kelompok }\end{array}$ & 85 & \\
\hline \multicolumn{4}{|c|}{ Jumlah skor perolehan } & 649 & 414 \\
\hline \multicolumn{4}{|c|}{ Jumlah skor maksimal $(4 \times 8 \times 25)$} & 800 & 800 \\
\hline \multicolumn{4}{|c|}{ Nilai } & 81 & 83 \\
\hline \multicolumn{4}{|c|}{ Kriteria } & $\begin{array}{l}\text { Sangat } \\
\text { Baik }\end{array}$ & $\begin{array}{l}\text { Sangat } \\
\text { Baik }\end{array}$ \\
\hline
\end{tabular}

Berdasarkan Tabel 3. di atas, terlihat ada peningkatan hasil belajar siswa ranah afektif pada siklus I sebesar 81 dengan kriteria hasil belajar sangat baikmeningkat pada siklus II menjadi 83 dengan kriteria hasil belajar sangat baik. Peningkatan tersebut terjadi pada hampir semua indikator afektif, yaitu pada aspek kemauan menerima, kemauan menanggapi, berkeyakinan, serta ketekunan dan ketelitian.

Peningkatan Hasil Belajar Ranah Psikomotor 
Peningkatan hasil belajar siswa ranah psikomotor dapat dilihat dari tabel 4 . Berdasarkan tabel 4 terlihat peningkatan hasil belajar ranah psikomotor pada siklus I sebesar 79 dengan kriteria hasil belajar dalam kategori baikmenjadi sebesar 83 dengan kategori sangat baik. Peningkatan tersebut terjadi pada semua indikator, baik pada aspek mekanisme, ataupun pada aspek persepsi dan respon terbimbing.
Berdasarkan pembahasan di atas, terlihat bahwa, penerapan pendekatan saintifik dengan metode diskusi kelompok dapat meningkatkan motivasi dan hasil belajar siswa ranah kognitif, afektif, dan psikomotor di kalangan siswa kelas V SDN Karanganyar Patikraja Banyumas pada mata pelajaran IPS materi Menghargai Perjuangan Para Tokoh dalam Mempertahankan Kemerdekaan.

Tabel 4.

Peningkatan Hasil Belajar Siswa Ranah Psikomotor

\begin{tabular}{|c|c|c|c|c|c|}
\hline \multirow[b]{2}{*}{ NO } & \multirow[b]{2}{*}{$\begin{array}{c}\text { INDIKATO } \\
\mathbf{R}\end{array}$} & \multirow[b]{2}{*}{ ITEM } & \multirow[b]{2}{*}{$\begin{array}{l}\text { KEMAMPUAN/ } \\
\text { KETERAMPILAN }\end{array}$} & \multicolumn{2}{|c|}{ SKOR } \\
\hline & & & & $\begin{array}{c}\text { SIKLUS } \\
\text { I }\end{array}$ & $\begin{array}{c}\text { SIKLUS } \\
\text { II }\end{array}$ \\
\hline \multirow[t]{2}{*}{1} & \multirow[t]{2}{*}{ Mekanisme } & $\bar{A}$ & $\begin{array}{l}\text { Menetapkan secara tepat } \\
\text { topik bacaan yang } \\
\text { ditelaah }\end{array}$ & 76 & 83 \\
\hline & & $\bar{B}$ & $\begin{array}{l}\text { Mengisi tabel tentang } \\
\text { peristiwa yang ditelaah } \\
\text { dengan tulisan yang rapi }\end{array}$ & 83 & 85 \\
\hline 2 & Persepsi & $\mathrm{C}$ & $\begin{array}{l}\text { Memerinci secara lengkap } \\
\text { aspek-aspek penting dari } \\
\text { peristiwa yang ditelaah }\end{array}$ & 77 & 82 \\
\hline \multirow[t]{2}{*}{3} & \multirow[t]{2}{*}{$\begin{array}{l}\text { Respon } \\
\text { terbimbing }\end{array}$} & D & $\begin{array}{lrr}\text { Mengisi tabel tentang } \\
\text { peristiwa yang ditelaah } \\
\text { secara tepat sesuai } \\
\text { petunjuk }\end{array}$ & 75 & 83 \\
\hline & & $\mathrm{E}$ & $\begin{array}{l}\text { Mengkomunikasikan } \\
\text { pendapat secara tepat } \\
\text { sesuai petunjuk }\end{array}$ & 82 & 81 \\
\hline \multicolumn{4}{|c|}{ Jumlah skor perolehan } & 393 & 414 \\
\hline \multicolumn{4}{|c|}{ Jumlah skor maksimal $(4 \times 5 \times 25)$} & 500 & 500 \\
\hline \multicolumn{4}{|c|}{ Nilai } & 79 & 83 \\
\hline \multicolumn{4}{|c|}{ Kriteria } & Baik & $\begin{array}{l}\text { Sangat } \\
\text { Baik }\end{array}$ \\
\hline
\end{tabular}

Perjuangan Para Tokoh dalam Mempertahankan Kemerdekaan. Hal itu terlihat dari perolehan hasil belajar ranah kognitif siswa pada siklus I diperoleh ratarata nilai sebesar 74 dengan ketuntasan 88 $\%$. Pada siklus II mengalami peningkatan menjadi rata-rata nilai sebesar 82 dengan ketuntasan $100 \%$. Hasil belajar ranah afektif pada siklus I diperoleh nilai sebesar 81 dan pada siklus II mengalami peningkatan menjadi 83 dengan kategori keduanya sangat baik. Hasil belajar ranah psikomotor diperoleh nilai pada siklus I sebesar 79 dengan kategori baik dan mengalami peningkatan pada siklus II menjadi 83 dengan kategori sangat baik.

Berdasarkan penelitian yang telah dilaksanakan, peneliti menyampaiakan saran Pertama, penerapan pendekatan saintifik dengan metode diskusi dalam 
pembelajaran hendaknya diawali dengan penyampaian instruksi kerja yang jelas dan terperinci bagi siswa dalam setiap langkah pembelajaran. Guru harus mengarahkan, memotivasi, membimbing, dan membantu

\section{SIMPULAN DAN SARAN}

Penelitian ini menyimpulkan bahwa:Pertama, Penerapan pendekatan saintifik dengan metode diskusi kelompok dapat meningkatkan motivasi belajar siswa pada mata pelajaran IPS materi Menghargai Perjuangan Para Tokoh dalam Mempertahankan Kemerdekaan pada siswa kelas V SDN 1 Karanganyar Tahun Pelajaran 2013-2014. Hal itu terlihat dari

Kedua, penerapan pendekatan saintifik dengan metode diskusi kelompok dalam pembelajaran perlu disertai perangkat pembelajaran berupa bahan ajar atau sumber belajar dan lembar kerja siswa sehingga setiap langkah saintifik (proses mengamati, mengumpulkan informasi, menanya, menalar, dan mengkomunikasikan informasi) melalui diskusi kelompok dapat berjalan secara optimal. Namun demikian, lembar kerja

\section{DAFTAR PUSTAKA}

Ahmadi, I.K. dan Amri, S. (2011). Mengembangkan Pembelajaran IPS Terpadu. Jakarta: PT. Prestasi Pustakaraya.

Ali, M. (2010). Guru Dalam Proses Belajar Mengajar. Bandung: Sinar Baru Algensindo.

Arikunto, S. (2012).Dasar-dasar Evaluasi Pendidikan. Jakarta: Bumi Aksara

Djamarah, S. B. (2010). Guru dan Anak Didik dalam Interaksi Edukatif, Suatu Pendekatan Teoretis dan Psikologis. Jakarta: Rineka Cipta.

Dimyati dan Mudjiono. (2009). Belajar dan Pembelajaran. Jakarta: Kerjasama Depdikbud dan Rineka Cipta.

Fathurrohman, P. dan Sutikno, M.Sobry. (2011). Strategi Belajar Mengajar. Bandung: PT. Refika Aditama.

Gafur, A. (2012). Desain Pembelajaran: Konsep, Model, dan Aplikasinya siswa dalam pelaksanaan langkah-langkah saintifik melalui diskusi kelompok, sehingga pembelajarn dapat berjalan optimal dan mencapai tujuan yang ditetapkan.

perolehan nilai motivasi siswa ketika mengikuti pembelajaran, baik pada siklus I maupun pada siklus II sebesar 82 dengan kriteria sangat baik.

Kedua,Penerapan pendekatan saintifik dengan metode diskusi kelompok dapat meningkatkan hasil belajar ranah kognitif, afektif, dan psikomotor siswa kelas V SDN 1 Karanganyar Patikraja Tahun Pelajaran 2013-2014 pada mata pelajaran IPS materi Menghargai

tersebut jangan terlalu besar bebannya sehingga tidak merubah proses berjalannya disksusi kelompok menjadi kerja kelompok.

Ketiga, guru hendaknya memotivasi dan menyuruh siswa yang kurang aktif dan pemalu dalam melaksanakan diskusi kelompok dengan cara berlatih memberikan pertanyaan, jawaban, kritikan, dan tanggapan pada selembar kertas, kemudian dipersilakan untuk membacakannya.

Dalam Perencanaan Pelaksanaan Pembelajaran. Yogyakarta: Ombak.

Hamalik. O. (2010). Proses Belajar Mengajar. Jakarta: PT. Bumi Aksara.

Hamruni. (2012). Strategi Pembelajaran. Yogyakarta: Insan Madani.

Harjanto. (2010). Perencanaan Pengajaran. Jakarta: Rineka Cipta.

Nasution, S. (2000). Berbagai Pendekatan dalam Proses Belajar dan Mengajar. Jakarta: Bumi Aksara.

Pusat Pengembangan Tenaga Kependidikan Kemendikbud. (2013). Materi Pelatihan Pendampingan Kurikulum 2013: Pendekatan Saintifik. Jakarta: Pusat Pengembangan Tenaga Kependidikan Kemendikbud.

Sardiman AM. (2000). Interaksi dan Motivasi Belajar Mengajar. Jakarta: Raja Grafindo Persada.

Satidjo. (2011). "Upaya Meningkatkan Prestasi Belajar Siswa Pada Mata 
Pelajaran IPS tentang Kenampakan Alam dan Keadaan Sosial Negara Tetangga Melalui Metode Diskusi Kelompok Pada Siswa Kelas VI SDN Babakan 01 Kawunganten". Skripsi pada Prodi PGSD FKIP Universitas Muhammadiyah Purwokerto.

Senen, A. (tt). Pendidikan IPS-SD. Yogyakarta: Prodi Pendidikan Guru Sekolah Dasar Fakultas Ilmu Pendidikan Universitas Negeri Yogyakarta

Sumaatmadja, Nursid. (1984). Metodologi Pengajaran Ilmu Pengetahuan Sosial (IPS). Bandung: Alumni

Suryani, N. dan Agung, L. (2012). Strategi Belajar Mengajar. Yogyakarta: Ombak

Suprijono, A. 2012. Cooperative Learning: Teori dan Aplikasi PAIKEM. Yogyakarta: Pustaka Pelajar. 